\title{
Krimpen zonder kramp : over demografische transitie en regionale arbeidsmarkten
}

Citation for published version (APA):

Cörvers, F. (2014). Krimpen zonder kramp : over demografische transitie en regionale arbeidsmarkten. Maastricht University. https://doi.org/10.26481/spe.20141010fc

Document status and date:

Published: 10/10/2014

DOI:

10.26481/spe.20141010fc

Document Version:

Publisher's PDF, also known as Version of record

\section{Please check the document version of this publication:}

- A submitted manuscript is the version of the article upon submission and before peer-review. There can be important differences between the submitted version and the official published version of record.

People interested in the research are advised to contact the author for the final version of the publication, or visit the DOI to the publisher's website.

- The final author version and the galley proof are versions of the publication after peer review.

- The final published version features the final layout of the paper including the volume, issue and page numbers.

Link to publication

\footnotetext{
General rights rights.

- You may freely distribute the URL identifying the publication in the public portal. please follow below link for the End User Agreement:

www.umlib.nl/taverne-license

Take down policy

If you believe that this document breaches copyright please contact us at:

repository@maastrichtuniversity.nl

providing details and we will investigate your claim.
}

Copyright and moral rights for the publications made accessible in the public portal are retained by the authors and/or other copyright owners and it is a condition of accessing publications that users recognise and abide by the legal requirements associated with these

- Users may download and print one copy of any publication from the public portal for the purpose of private study or research.

- You may not further distribute the material or use it for any profit-making activity or commercial gain

If the publication is distributed under the terms of Article $25 \mathrm{fa}$ of the Dutch Copyright Act, indicated by the "Taverne" license above, 
Maastricht University

Krimpen zonder kramp:

Over demografische transitie en

regionale arbeidsmarkten

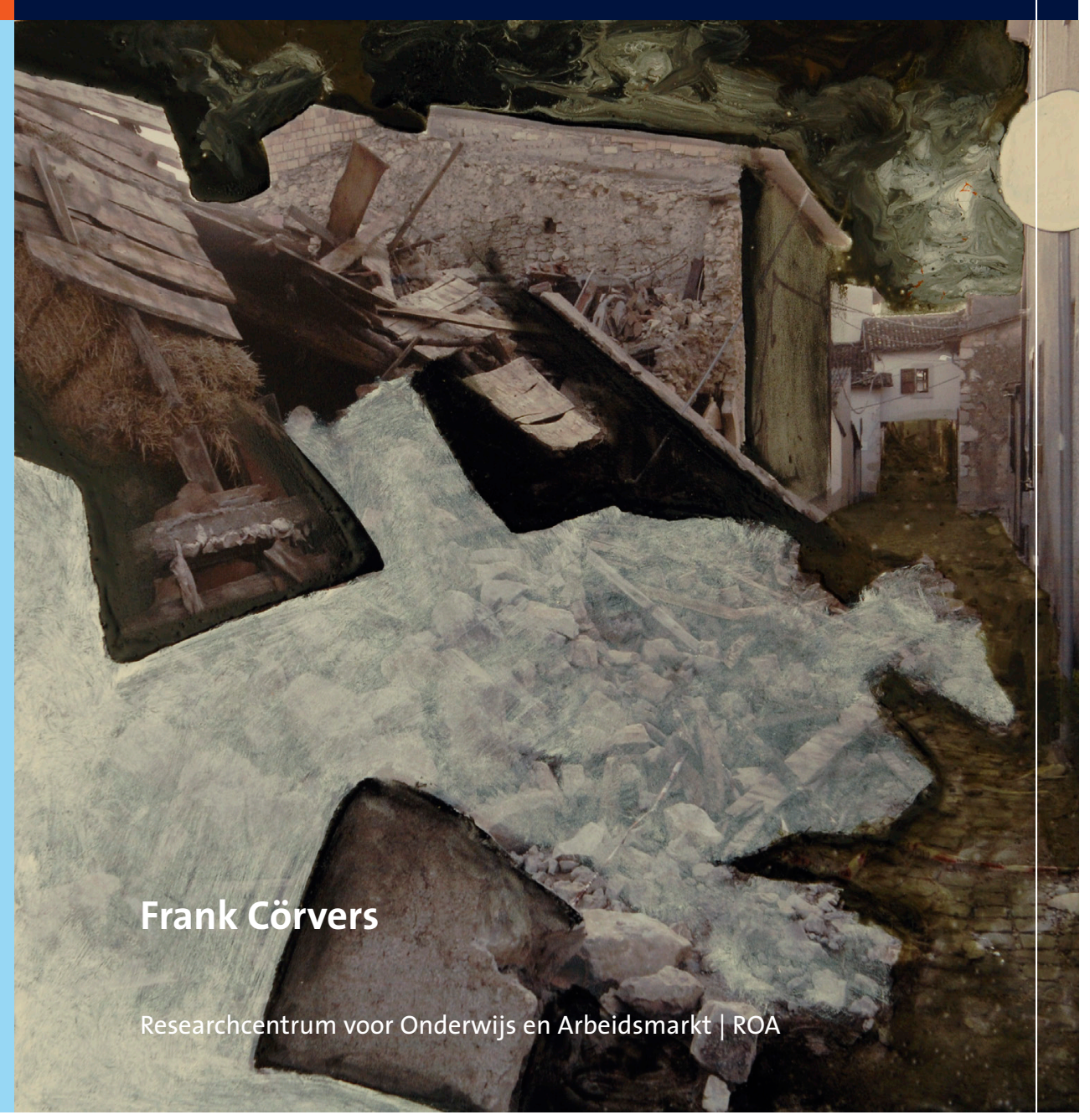


@ Schilderij kaft: Jacqueline van Dongen www.nurff.nl

Fotografie: Calja Hellebrand-de Bruijn 
Krimpen zonder kramp:

Over demografische transitie en

regionale arbeidsmarkten 


\section{Colofon}

Ontwerp en print: Océ Business Services, Maastricht

ISBN: 978-90-5321-532-6

NUR: 780

Alle rechten voorbehouden. Niets uit deze uitgave mag worden verveelvoudigd, opgeslagen in een geautomatiseerd gegevensbestand of openbaar gemaakt worden, zonder voorafgaande schriftelijke toestemming van de auteur of uitgever. 


\section{Krimpen zonder kramp:}

\section{Over demografische transitie en regionale arbeidsmarkten}

Rede, in verkorte vorm uitgesproken bij de openbare aanvaarding van het ambt van hoogleraar Demografische Transitie, Menselijk Kapitaal en Werkgelegenheid aan de Universiteit Maastricht

Maastricht, 10 oktober 2014

Door Prof.dr. Frank Cörvers 

Geachte Rector, dames en heren,

\section{Inleiding}

Dat ik vandaag in Limburg aan de Universiteit Maastricht kom te spreken over demografische krimp is geen toeval. Juist deze provincie wordt geconfronteerd met krimp. Zo is Zuid-Limburg een door de Nederlandse regering erkende krimpregio, naast Noordoost-Groningen en Zeeuws-Vlaanderen (Rijk/VNG/IPO, 2011). Er is sprake van een krimpregio wanneer meerdere buurgemeenten substantieel en structureel krimpen qua bevolking en aantal huishoudens. Bovendien worden er tien zogenoemde anticipeerregio's onderscheiden, waaronder ook Midden- en Noord-Limburg vallen. Voor anticipeergebieden wordt er vanuit gegaan dat in de periode 2010-2020 en/of 2020-2040 de bevolking en/of het aantal huishoudens daalt.

\section{Figuur 1}

De krimp-en anticipeerregio's van Nederland

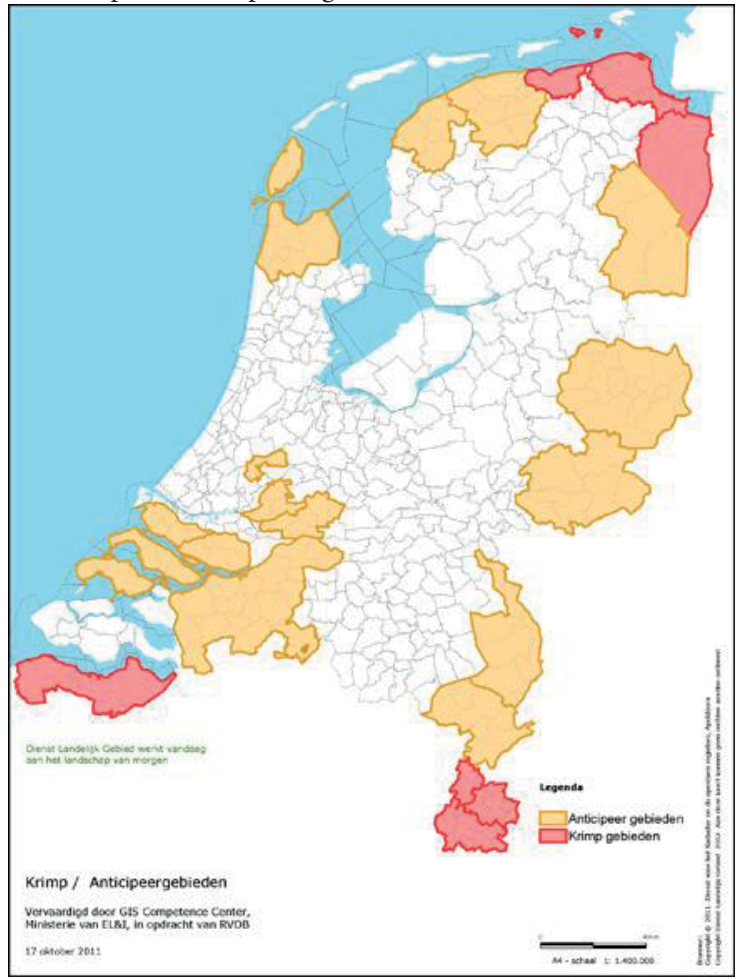

Bron: Rijk/VNG/IPO (2011) 
In krimpgebieden is de demografische krimp zichtbaar en voelbaar in het alledaagse leven vanwege onder meer leegstand en verschraling van allerlei voorzieningen (Hospers, 2010; OECD, 2012; Reverda, 2011; Reverda et al., 2012). In veel Limburgse gemeenten is er sprake van een aanzienlijke bevolkingsdaling, welke naar verwachting zal aanhouden tot 2040 (Huisman et al., 2013). Bovendien is er sprake van een grote verandering in de samenstelling naar leeftijd. Demografische transitie, in de vorm van bevolkingsdaling, vergrijzing en/of ontgroening, kan op velerlei wijze diep ingrijpen op een lokale samenleving. Dit fenomeen komt wereldwijd voor, in qua aard en karakter heel verschillende regio's, met diverse oorzaken van krimp, en met uiteenlopende creatieve oplossingsrichtingen om met bevolkingskrimp om te gaan. Om zo goed mogelijk voorbereid te zijn op de demografische krimp vinden in de Nederlandse krimp- en anticipeerregio's experimenten en onderzoeken plaats op het gebied van wonen, onderwijs, zorg, voorzieningen en burger- en publieksparticipatie. Ik wil in mijn rede eerst ingaan op de oorzaken van bevolkingskrimp. Vervolgens wil ik bespreken welke de oorzaken zijn van de kramp en hoe deze verlicht kan worden. Daarna leg ik de relatie met de arbeidsmarkt.

\section{Wat veroorzaakt krimp?}

Bevolkingskrimp is het resultaat van twee demografische ontwikkelingen die moeilijk beïnvloedbaar zijn, maar sterk kunnen verschillen tussen regio's, namelijk het geboortesaldo en het migratiesaldo. Dit zal ik hieronder verder toelichten. Ik gebruik hoofdzakelijk de provincie Limburg als voorbeeld.

\section{Geboortesaldo}

Het vruchtbaarheidscijfer fluctueert over de jaren, maar verschillen tussen regio's zijn vrij stabiel. Dit wordt geilllustreerd in figuur 2. De figuur geeft het gemiddelde kindertal per vrouw weer voor Nederland en de drie Limburgse regio's. De vervangingsratio van 2,1 om de bevolkingsomvang stabiel te houden wordt niet gehaald. Er is eind jaren 90 een structurele toename geweest doordat de cohorten van vrouwen die hun zwangerschap hadden uitgesteld kinderen kregen. Het is verder duidelijk dat de vruchtbaarheid in Zuid-Limburg met een vervangingsratio van 1,4 à 1,5 laag is ten opzichte van Nederland en de andere twee Limburgse regio's. Dit is één van de belangrijke oorzaken voor de bevolkingskrimp in ZuidLimburg (De Grip en Van Thor, 2013). 


\section{Figuur 2}

Vruchtbaarheid gemeten als gemiddeld kindertal per vrouw, Nederland en de drie Limburgse regio's, 1988-2013

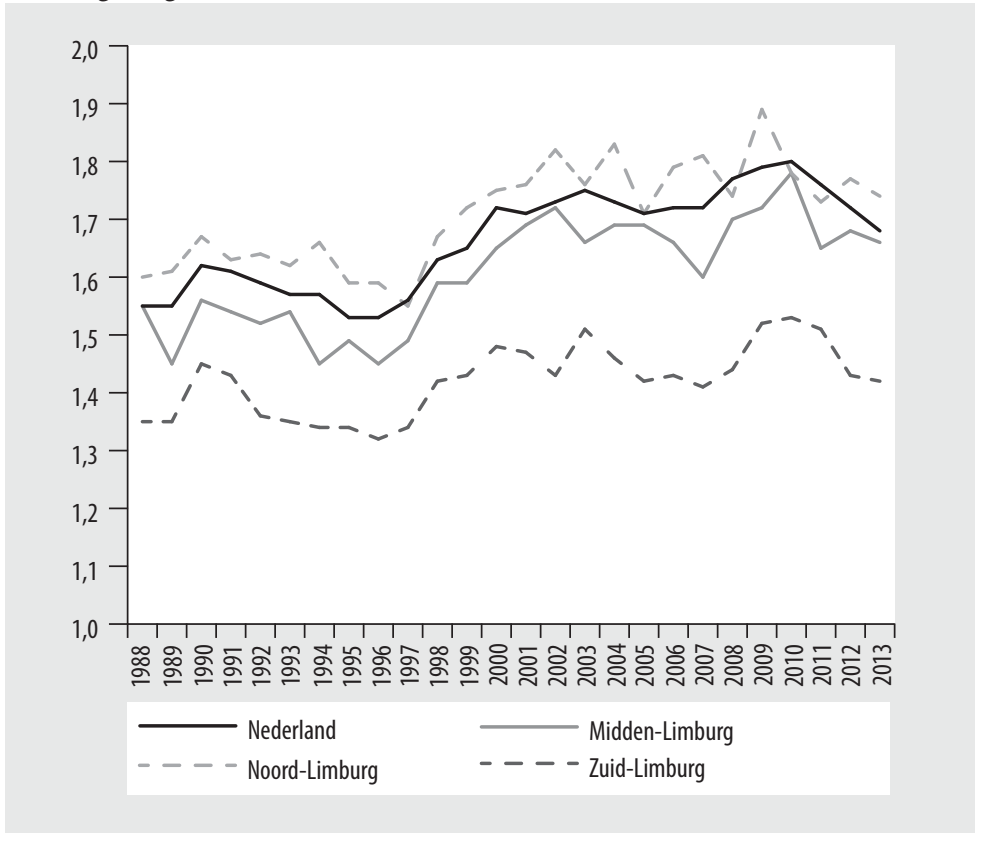

\section{CBS (Statline)}

In figuur 3 wordt per 1.000 inwoners het aantal levendgeborenen en overledenen in Nederland en Limburg weergegeven voor de periode 1960-2013. Duidelijk is dat het geboortecijfer aanzienlijk is gedaald sinds de jaren zestig. In Limburg (en Noord-Brabant) was de vruchtbaarheid tot in de jaren vijftig het hoogst van alle regio's door de invloed van de katholieke kerk. Pas na 1960 daalde de vruchtbaarheid door ontkerkelijking en anticonceptie (Langeweg, 2011). In Limburg veel sterker dan elders, tot zelfs het laagste vruchtbaarheidsniveau van het land. Dus van het ene uiterste naar het andere. In de jaren tachtig en negentig stabiliseerde het geboortecijfer enigszins, maar daarna is het verder afgenomen. Het sterftecijfer neemt door de vergrijzing gestaag toe in het hele land. Qua sterftecijfer wordt Nederland in de eerste helft van de jaren negentig overtroffen door Limburg omdat daar de vergrijzing sterker is. Voor Limburg als geheel werd het sterftecijfer in 2005 voor het eerst groter dan het geboortecijfer. Voor Limburg was er sindsdien een zogenoemd geboortetekort. In Zuid-Limburg werd het geboortesaldo al vijf jaar daarvoor negatief. Voor Nederland blijft er voorlopig nog een positief geboortesaldo, waardoor er een natuurlijke aanwas is. 


\section{Figuur 3}

Geboorte- en sterftecijfer, aantal per 1.000 inwoners in Nederland en Limburg, 1960-2013

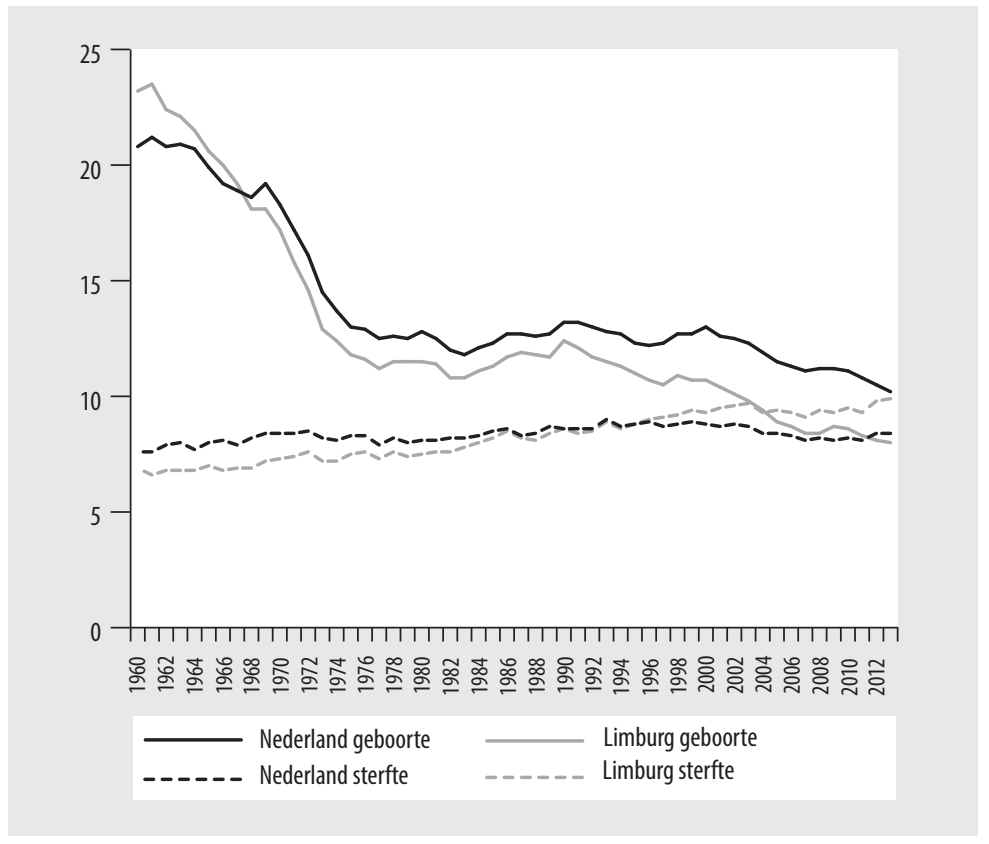

Bron: CBS (Statline)

\section{Migratiesaldo}

Er zijn binnen Nederland regio's en gemeentes met aanzienlijke migratietekorten, en andere met flinke migratieoverschotten. Ik onderscheid hier buitenlandse van binnenlandse migratiestromen. Ten eerste de migratie met het buitenland. Deze is tamelijk grillig, en uiteraard spelen bij immigratie ook internationale ontwikkelingen in verband met oorlog en andere rampspoed een rol, evenals de regelgeving en uitvoering omtrent asielaanvragen, de overgangsregeling van tewerkstellingsvergunningen voor inwoners van de Midden- en Oost-Europese landen, en de kennismigrantenregeling (WODC, 2009). Desondanks blijken immigratie en emigratie tamelijk sterk af te hangen van de economische groei in ons land. Een stijging van de economische groei leidt na één of twee jaar tot een stijging van het aantal immigranten en een daling van het aantal emigranten (Cörvers et al., 2009). Dat betekent dat ook het verschil tussen immigratie en emigratie, het zogeheten immigratiesaldo, na enige tijd toeneemt bij een verhoging van de economische groei. 
Ter illustratie wordt in figuur 4 het immigratiesaldo per 1.000 inwoners op de linker-as weergegeven, en vergeleken met de economische groei van twee jaar daarvoor op de rechter-as. De hoge economische groei van begin tachtiger jaren, begin negentiger jaren en begin deze eeuw gaat gepaard met een surplus aan immigranten ten opzichte van emigranten. De terugval in economische groei die daarop volgde leidde tot een daling van het immigratiesaldo. Tussen 2003 en 2007 was het immigratiesaldo zelfs negatief. De grote recessie die in 2009 zichtbaar was door de sterke negatieve economische groei in dat jaar, leidde echter niet tot een sterke daling van het immigratiesaldo. Dat kwam waarschijnlijk door het abrupte karakter van de economische neergang. Het zal geen verrassing zijn dat de samenhang tussen migratie en economische groei ook in veel regio's is terug te zien.

\section{Figuur 4}

Immigratiesaldo per 1.000 inwoners (linker-as) en met 2 jaar vertraagde BBPgroei in \% (rechter-as), Nederland, 1980-2013

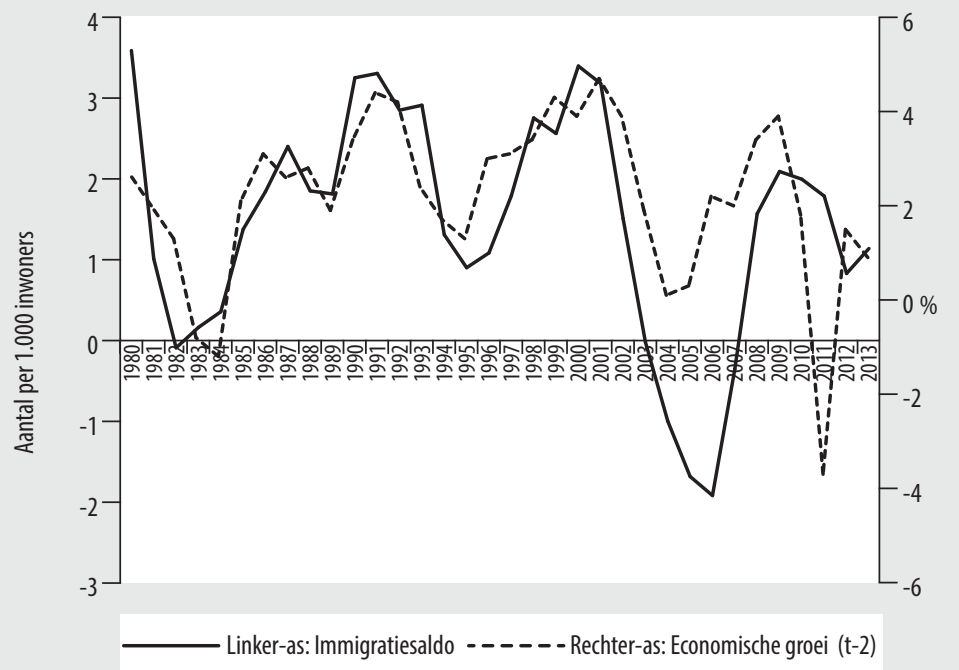

Bron: CBS (Statline)

De verklaring voor het verband in figuur 4 is dat immigratie en emigratie voor een belangrijk deel worden angezwengeld of afgeremd door de situatie op de arbeidsmarkt. Ruim een kwart van de immigranten en bijna de helft van de emigranten heeft de Nederlandse nationaliteit. Onder de Nederlandse migranten is waarschijnlijk een groot deel 'grensmigrant' 
vanwege woonmigratie. Echter van de niet-Nederlandse immigranten is ca. $40 \%$ arbeidsmigrant. Onder de niet-Nederlandse immigranten is arbeid het belangrijkste migratiemotief. ${ }^{1}$ Werkgevers trekken arbeidsmigranten aan in tijden van een krappe arbeidsmarkt, en de arbeidsmigranten komen of gaan afhankelijk van de arbeidsmarktsituatie. Eenzelfde soort verband als tussen migratie en economische groei kan dan ook worden getoond voor migratie en werkloosheid of vacatures. Een implicatie hiervan is dat de migratie met het buitenland een belangrijk aanpassingsmechanisme is op de Nederlandse arbeidsmarkt. Discrepanties op de Nederlandse arbeidsmarkt, vaak tekorten of overschotten genoemd, worden doorgaans verminderd door internationale migratie.

In figuur 5 is voor de periode van 1988 tot 2013 te zien dat het Limburgse immigratiesaldo min of meer meebeweegt met het verloop voor Nederland als geheel. Limburg heeft een groot aandeel in het Nederlandse immigratiesaldo. In 2013 heeft Limburg na Noord-Holland en Noord-Brabant het in absolute zin grootste immigratiesaldo van alle provincies. De laatste jaren kwamen er 2.500 à 3.000 immigranten per jaar Limburg binnen. In Limburg is ook het relatieve immigratiesaldo hoog, dat wil zeggen het netto aantal immigranten per 1.000 inwoners. Dit relatieve immigratiesaldo is na Flevoland het grootst in de provincies Groningen, Zeeland en Limburg waarbinnen de grootste krimpgebieden gelegen zijn. De verklaringen voor Limburg zijn divers. Uiteraard is van belang dat Limburg een grensregio is die een langere grens heeft met het buitenland dan met de rest van Nederland. Er zijn veel woonmigranten uit Duitsland. Daarnaast worden er vanwege de agrarische bedrijvigheid in Noord-Limburg veel immigranten uit Midden- en Oost-Europa (MOE-landers) aangetrokken, vooral uit Polen (Cörvers et al., 2009; Kooiman et al., 2013). Bovendien oefenen internationale bedrijven en de Universiteit Maastricht grote aantrekkingskracht uit op buitenlandse werknemers. Vooral in Maastricht en Venlo is er tussen 2007 en 2012 een sterke toename geweest van het aantal arbeids- en kennismigranten (Decisio, 2014).

1 De arbeidsmigratie is tegenwoordig groter dan de gezinsmigratie (CBS, Statline; zie ook Cörvers et al., 2009). In 1995 had nog slechts $15 \%$ van de niet-Nederlandse migranten het verrichten van arbeid als belangrijkste motief. 


\section{Figuur 5}

Immigratiesaldo in aantal migranten, Nederland en Limburg, 1988-2013

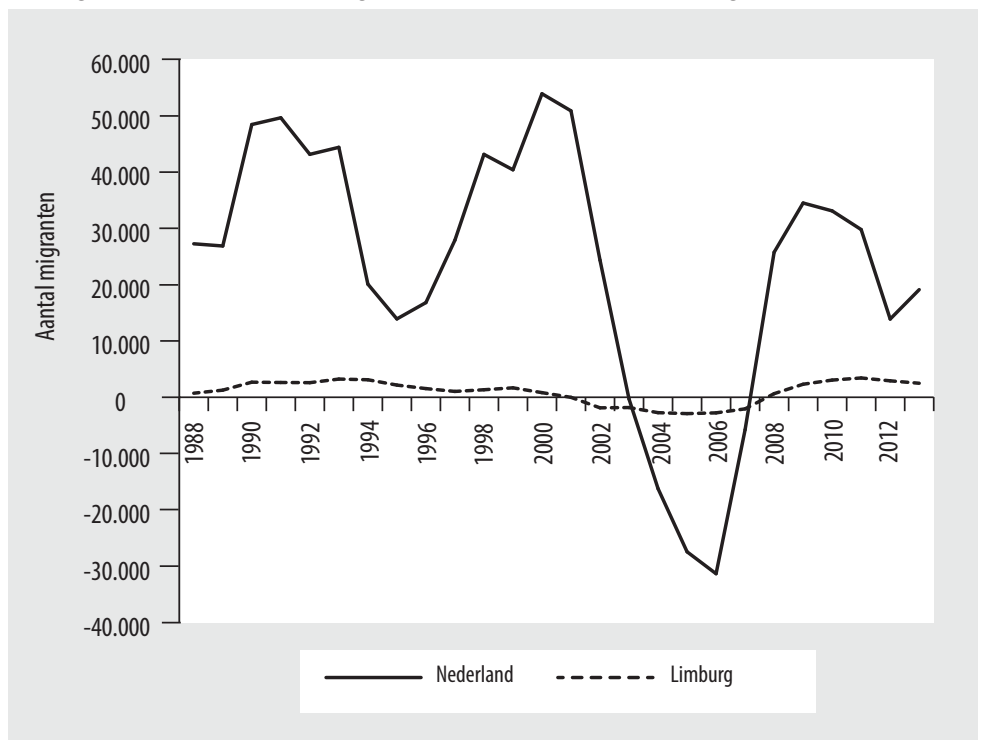

Bron: CBS (Statline)

Zoals gezegd bestaat het totale migratiesaldo behalve uit de buitenlandse ook uit de binnenlandse migratie, dat wil zeggen het aantal verhuizingen naar een andere regio. In figuur 6 wordt de binnenlandse migratie per provincie weergegeven voor het jaar 2013. Limburg is wat betreft de binnenlandse verhuizingen feitelijk al jarenlang de provincie met het grootste verschil tussen het aantal mensen dat vertrekt en komt. Ook in relatieve zin, dat wil zeggen de migratie per 1.000 inwoners, behoort Limburg tot de helft van de provincies met een groot binnenlands migratietekort. Bij nadere analyse van de migratiepatronen blijkt dat er flinke veranderingen kunnen optreden in de migratiesaldo's: voor provincies zoals Drenthe en Zeeland slaan ze van het ene naar het andere moment om van een migratie-tekort naar een -overschot, en weer terug naar een tekort gedurende de laatste jaren. Uit CBS-cijfers vanaf 1991 blijkt dat in Flevoland het voorheen erg grote positieve saldo continue is gedaald, en nu negatief is. Voor Zuid- en vooral Noord-Holland is er juist een omslag geweest naar een positief migratiesaldo. Limburg en Friesland zijn de enige provincies met elk jaar een migratietekort. Utrecht en Gelderland hebben vrijwel onafgebroken een migratieoverschot. Overijssel en Groningen hebben meestal een migratietekort, NoordBrabant heeft in de meeste jaren een migratieoverschot. 


\section{Figuur 6}

Binnenlands migratiesaldo per provincie, 2013

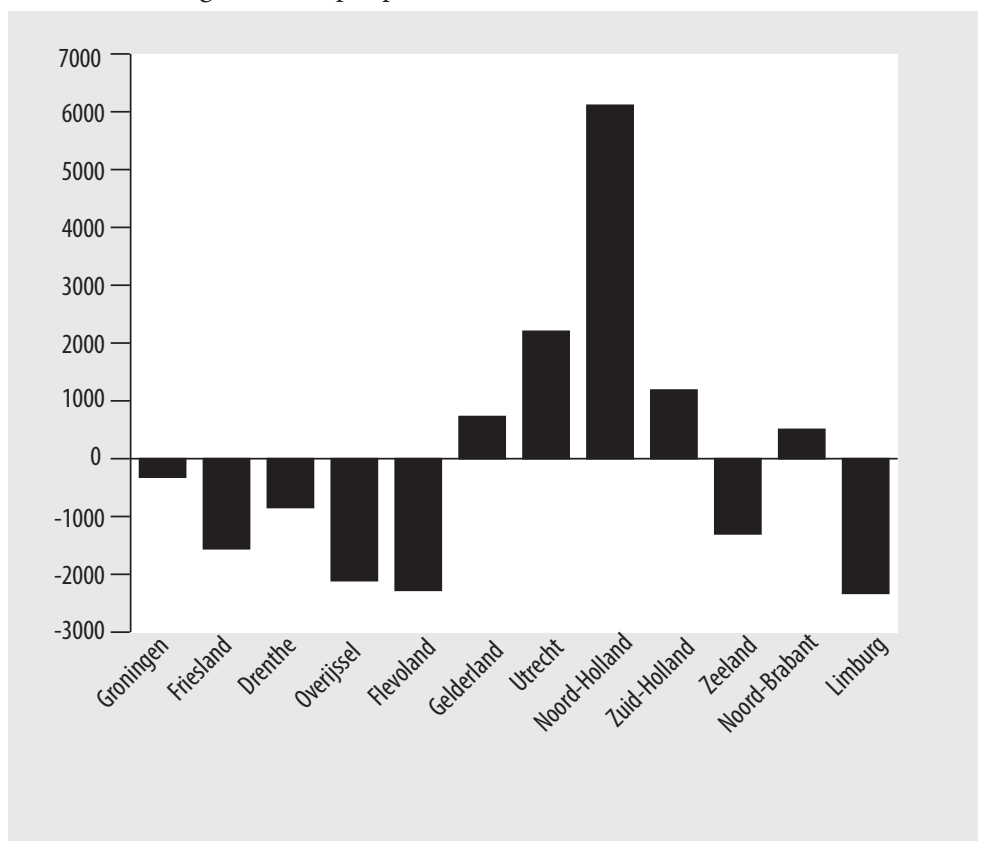

Bron: CBS (Statline)

Alvorens in te gaan op enkele verklaringen voor de binnenlandse migratiepatronen, laat ik in figuur 7 eerst het resultaat zien van de optelsom van geboortesaldo en migratiesaldo voor Limburg. Zoals eerder besproken vertoont het geboortesaldo een sterke negatieve trend. Daardoor is er de laatste jaren een geboortetekort. Limburg was jarenlang de enige provincie met een geboortetekort. Sinds 2010 is daar Zeeland bij gekomen. Limburg is ook om een andere reden extreem, want Limburg heeft het grootste binnenlandse migratietekort. Dit negatieve saldo werd in de jaren 2009 tot en met 2012 meer dan gecompenseerd door de netto instroom van buitenlandse migranten. In 2013 is de netto instroom van buitenlandse migranten in Limburg echter ongeveer even groot als de netto verhuisstroom vanuit Limburg naar andere regio's van Nederland. De Limburgse bevolking is in 2013 dan ook bij benadering gekrompen met het negatieve geboortesaldo, ofwel het geboortetekort. Voor Noorden in mindere mate Midden-Limburg hebben we eerder gezien dat het geboortesaldo veel hoger ligt, vanwege de hogere vruchtbaarheid. Daardoor is in Noord- en Midden-Limburg de bevolking gemiddeld over de laatste jaren niet gekrompen. 


\section{Figuur 7}

Bevolkingsontwikkeling in Limburg met geboorte- en migratiesaldo, 1991-2013

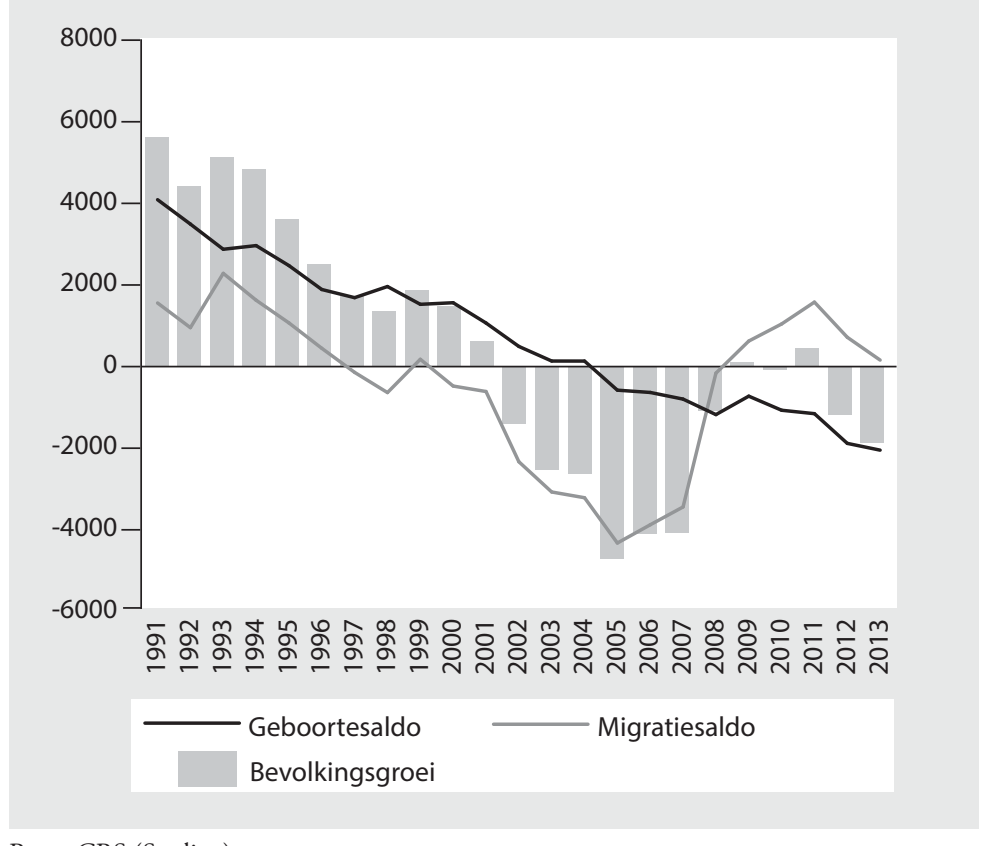

Bron: CBS (Statline)

\section{Binnenlandse migratie en agglomeratievoordelen}

De vraag waarop ik hier nog kort wil ingaan is waarom sommige regio's kennelijk aantrekkelijker zijn om naar toe te verhuizen dan andere. Daarbij rijst de vraag of deze redenen aansluiten bij het beleid vanuit provincies en regio's om de eigen streek te promoten als aantrekkelijke woon- en werkregio. De campagne voor Zuid-Limburg is een nationaal bekend voorbeeld. Deze begon in 2010 met "The Bright Side of Life", daarna gevolgd door 'Zuid-Limburg, je zal er maar wonen". Vanuit de eerder gepresenteerde cijfers bezien, lijkt er nauwelijks effect te zijn van de campagne op het binnenlandse migratiesaldo: dat is al jaren negatief met een vertrekoverschot van ongeveer 1.000 mensen per jaar, dat is tussen de 1,5 en 2 promille. Maar je weet natuurlijk niet wat er zou zijn gebeurd als deze campagnes niet waren opgestart.

Vanuit het regionale beleid is er altijd veel aandacht voor initiatieven gericht op woningbouwprogramma's en voor plannen om de econo- 
mische bedrijvigheid te stimuleren of regio's aantrekkelijker te maken qua bereikbaarheid (wegen, vliegvelden, openbaar vervoer, etc.), cultuur, leefomgeving en recreatie. Dat heeft er wellicht deels mee te maken dat het aantrekken van mensen uit andere regio's gemakkelijker te beïnvloeden lijkt en politiek gezien beter te verteren is dan bijvoorbeeld het direct stimuleren van het aantal geboortes en het aantrekken van meer buitenlandse migranten. Zoals aangegeven is de binnenlandse migratiedynamiek op provincieniveau groot. De analyse op provincieniveau doet echter geen recht aan de onderliggende dynamiek op het niveau van gemeentes.

Uit onderzoek van het Centraal Bureau voor de Statistiek en het Planbureau van de Leefomgeving (Huisman et al., 2013) blijkt dat de bevolking in de vier grote steden Amsterdam, Rotterdam, Utrecht en Den Haag sinds 2007 ongeveer twee keer zo hard is gegroeid als in de middelgrote gemeentes (boven de 100.000 inwoners) en wel vijf keer zo hard als in de overige gemeentes. Volgens Huisman et al. (2013) is de bevolkingsgroei in de vier grote steden tussen 2002 en 2012 voor de helft of meer te danken aan de Vinex-wijken. Door deze nieuwbouwlocaties blijven jong volwassenen steeds vaker in de grote steden wonen als ze een gezin vormen, zelfs met opgroeiende kinderen. Ook de komende jaren zal er naar verwachting nog veel gebouwd worden in de grote steden. Tot 2025 zullen ze tezamen naar verwachting ruim twee keer zo snel groeien als het landelijk gemiddelde.

Een dergelijke concentratie van de bevolking in de grote steden van Nederland kan worden verklaard door de samenhang tussen bevolkingsen werkgelegenheidsgroei. ${ }^{2}$ In empirisch onderzoek wordt inderdaad een wederkerige relatie gevonden, die past binnen de theorie van de 'cumulatieve causatie' geïntroduceerd door Myrdal (1957). Als de werkgelegenheid op een locatie groeit, trekt dat werkzoekenden aan die zich volgens het zogeheten monocentrische model zo dicht mogelijk bij hun baan vestigen. Hierdoor groeit de regionale bevolking, en vervolgens de werkgelegenheid in dienstverlenende sectoren zoals zorg en onderwijs, waardoor er nog meer werkzoekenden komen en de bevolking verder groeit, etc. Dit leidt tot een positieve spiraal in specifieke gebieden.

In de Angelsaksische literatuur wordt er vaak vanuit gegaan dat de bevolking zich daar vestigt waar economische activiteit en werkgelegenheid is. In de neoklassieke handelstheorie worden de economische activiteiten en de

2 Zie voor een overzicht van de literatuur over woon-werk dynamiek De Graaf et al. (2008). 
bijbehorende werkgelegenheid bepaald door de comparatieve voordelen van landen. Binnen deze landen zijn dat bijvoorbeeld gebieden die aan zee of aan een rivier liggen of waar zich grondstoffen als gas of kolen bevinden.

Nieuwere theorieën leggen er de nadruk op dat bedrijven zich bij voorkeur vestigen in elkaars nabijheid, vanwege de agglomeratievoordelen die daaraan verbonden zijn. ${ }^{3}$ De agglomeratievoordelen hebben ten eerste betrekking op de gezamenlijke toegang tot de plaatselijke infrastructuur (zoals wegen en vliegvelden), tot hoogwaardige intermediaire producten en diensten van leveranciers en tot eenzelfde grote 'pool' van specialisten en kenniswerkers op de regionale arbeidsmarkt (Glaeser en Mare, 2001). Daarnaast kunnen bedrijven in elkaars nabijheid beter profiteren van kennis-spillovers, wat kan leiden tot een hogere innovatiegraad. Door grotere agglomeraties zijn er tevens meer mogelijkheden voor productdifferentiatie, waardoor bedrijven en instellingen beter kunnen inspelen op de uiteenlopende voorkeuren van consumenten. Dat betekent omgekeerd dat ook consumenten voordeel hebben van een breder aanbod van winkels, horeca, recreatie, cultuur en onderwijs (Glaeser et al., 2001). Werknemers kunnen profiteren van een groter aanbod aan banen, wat vooral van voordeel is als ze hoogopgeleid zijn, specifieke kennis hebben en hun partner eveneens een baan op pendelafstand zoekt. Verder kunnen vooral hoger opgeleiden via formele en informele kennisuitwisseling productiviteitsvoordelen behalen als ze zich vestigen in steden (Rauch, 1993). Concentratie van bevolking en werkgelegenheid heeft dus allerlei voordelen voor bedrijven, consumenten en werknemers. Deze voordelen vertalen zich in een hoger productiviteits- en inkomensniveau in dichtbevolkte ten opzichte van minder dichtbevolkte gebieden (Ciccone, 2002; Ciccone and Hall, 1996; Groot et al. 2014).

Dichtbevolkte gebieden kunnen zich aan de randen uitbreiden als er in de kern negatieve externe effecten ontstaan vanwege de stijging van grondprijzen en de overbelasting van de infrastructuur. Perifere gebieden die ver weg van de kern gelegen zijn lopen echter door de cumulatieve causatie het risico om in een negatieve spiraal terecht te komen (Hospers, 2010). Groei en krimp zijn dus, vooral waar het de binnenlandse migratie betreft, met elkaar verbonden. Het totaal van de binnenlandse migratie in Nederland is immers per definitie gelijk aan nul. De binnenlandse

3 Brakman et al. (2003) spreken van "first-nature and second-nature determinants of location choice" om te verwijzen naar het belang van respectievelijk natuurlijke factorbeschikbaarheden en agglomeratievoordelen bij de vestiging van bedrijven en instellingen. Ze benadrukken dat de bijbehorende theorieën eerder complementair zijn dan concurrerend. 
migratie is een 'zero sum game', als je het ziet als een spel van regio's en gemeentes om hun bevolking te laten groeien, of op zijn minst op hetzelfde niveau te houden. Dat wil zeggen dat de winst van de ene regio gaat ten koste van een andere regio.

Zoals gezegd wordt er in de internationale literatuur vanuit gegaan dat wonen werken volgt. Agglomeratievoordelen door geconcentreerde werkgelegenheid is doorslaggevend voor de bevolkingsgroei. In de Nederlandse literatuur blijkt dat echter deels andersom te zijn. Uit onderzoek van De Graaff (2008) over de periode 1996-2005 blijkt dat vooral in de Randstad het werk het wonen volgt. Dat betekent vrij vertaald dat over deze periode het bouwen van woningen leidde tot bevolkingsaanwas, en vervolgens door cumulatieve causatie tot werkgelegenheidsgroei. Dat kan zijn omdat bedrijven zich willen vestigen in de buurt van het arbeidspotentieel, en/of omdat ze daar hun producten en diensten kunnen afzetten. Dit effect geldt alleen in de Randstad, waar Vinex-gemeentes een nationale opgave hebben om woningen te bouwen. Zij zien om deze reden dus op termijn ook de werkgelegenheid groeien. Dezewerkgelegenheidsgroei heeft vooral betrekking op overheid, onderwijs en detailhandel. Buiten de Randstad heeft het bouwen van woningen om bevolkingskrimp tegen te gaan weinig zin. In de perifere gebieden is er slechts een klein en niet-significant effect van werkgelegenheidsgroei op bevolkingsgroei, bijvoorbeeld via investeringen in bedrijventerreinen. Dat binnen de Randstad in afwijking van de internationale dynamiek werken wonen volgt, komt doordat er vanwege alle beperkingen in de regelgeving slechts weinig locaties zijn voor woningbouw. Bedrijven en instellingen spelen daardoor relatief flexibel in op daar waar de bevolking wel groeit.

\section{Nuanceringen}

Op mijn analyse over de bevolkingskrimp in Limburg valt het nodige af te dingen en aan te vullen. Ik zal dat hieronder samenvatten.

1. Het aantal huishoudens groeit wel en tot 2025 is er in geen enkele regio krimp van het aantal huishoudens (Huisman et al., 2013). De gemiddelde huishoudensgrootte daalt en blijft dalen doordat mensen vaker en langer alleen wonen. Dat is vooral van belang voor de omvang en samenstelling van woningbouwprogramma's. 
2. De verandering in de samenstelling van de bevolking is belangrijker dan de verandering van de omvang. Dit geldt niet alleen voor de huishoudenssamenstelling, maar ook voor de afname van het aantal jongeren en de toename van het aantal gepensioneerden en $80+$-plussers. Voor het onderwijs is uiteraard de ontgroening van belang, voor de zorg de vergrijzing. Vanuit arbeidsmarktperspectief draait het vooral om de omvang en het verloop van de potentiële beroepsbevolking.

3. Binnen provincies kunnen er tussen gemeentes grote verschillen bestaan in bevolkingsgroei. Binnen de krimpprovincies zijn er gemeentes met zowel grote groei als grote krimp. Zo groeit de stad Groningen, maar krimpt het aangrenzende Noordoosten van de provincie Groningen. In Maastricht is er veel minder krimp dan in Parkstad Limburg door de aanwezigheid van de universiteit. Maar ook binnen de Randstadprovincies zijn er gebieden met bevolkingskrimp. De anticipeerregio's Kop van Noord-Holland, Groene Hart en delen van Zuid-Holland zijn de afgelopen tien jaar gekrompen. Maar feitelijk had elke provincie, met uitzondering van Flevoland, de afgelopen 10 jaar meerdere krimpgemeentes binnen zijn grenzen. Het aantal krimpgemeentes zal de komende jaren alleen maar groter worden.

4. De oorzaken van krimp in termen van geboortetekort en binnenlands en buitenlands migratietekort kunnen per regio heel verschillend zijn. Zo heeft Zeeland in tegenstelling tot Limburg geen volwaardige universiteit, waardoor veel jongeren buiten de provincie gaan studeren en daar blijven wonen. Retourmigratie van gezinnen met jonge kinderen compenseerde dit tot enige jaren geleden, maar dat lijkt nu voorbij te zijn (Cörvers, 2013). In de provincie Groningen werkt het zogeheten 'roltrapmodel': jongeren van de dorpen trekken eerst naar de stad Groningen om te studeren, waarna ze vaak in aangrenzende dorpen gaan wonen of richting de Randstad verhuizen om carrière te maken (Venhorst, 2012);

5. Onderbelicht in mijn eerdere analyse is het belang van Limburg als grensregio. Marlet et al. (2014) illustreren in een recente publicatie dat vooral grensregio's last hebben van agglomeratienadelen vanwege de zogeheten grensweerstand. Daardoor zijn veel potentieel interessante banen niet of moeilijk bereikbaar voor afgestudeerden en werkzoekenden uit Limburg, tenzij ze werk zoeken en verhuizen naar een ander deel van Nederland. Niet alleen is het aan de overzijde van de grens moeilijker zoeken naar een baan door gebrek aan informatievoorzieningen, ook zijn er ingewikkelde belasting- en sociale zekerheidskwesties, en zijn er taal- en culturele verschillen. Marlet et 
al. (2014) wijzen op de negatieve spiraal die daardoor ontstaat in met name grensregio's. Doordat jongeren wegtrekken en de bevolking krimpt, verschralen de voorzieningen, ontstaat er leegstand en dalen de huizenprijzen. Bovendien zijn de achterblijvers in de grensregio's relatief oud en laag opgeleid, en hebben ze relatief vaak een gesubsidieerde baan of ontvangen ze een uitkering.

\section{Toekomstige arbeidsmarkt}

De bevolkingskrimp heeft direct invloed op de ontwikkeling van de potentiële beroepsbevolking. De potentiële beroepsbevolking wordt vaak gedefinieerd als de bevolking van 20 tot 65 jaar oud. In de bijgaande figuur is te zien dat de potentiële beroepsbevolking in Nederland tussen 2014 en 2025 met bijna 2\% daalt. Voor Groningen stijgt de potentiële beroepsbevolking aanvankelijk zelfs nog iets, maar daalt deze naar verwachting vanaf 2025. Dat deze provincie redelijk stabiel blijft qua omvang komt doordat de stad Groningen sterk groeit, deels ten koste van de krimpgebieden in Noordoost-Groningen. In Limburg is de potentiële beroepsbevolking in 2025 met 10\% gedaald, in Zuid-Limburg meer dan in Noord-en Midden-Limburg. In Zeeland is de daling wat minder sterk, en is de krimp in Zeeuws-Vlaanderen groter dan in de rest van Zeeland.

Tegenwoordig wordt de potentiële beroepsbevolking steeds vaker gecorrigeerd voor de stijging van de AOW-leeftijd. Deze loopt op van 65 jaar tot 67,5 jaar in 2025. In 2011 en 2012 was er in Nederland voor het eerst een afname van de leeftijdsgroep 20 tot 65 jaar. Door de stijging van de AOW-leeftijd neemt de potentiële beroepsbevolking in Nederland vanaf 2016 toe, om vanaf 2025 weer te krimpen. De Nederlandse potentiële beroepsbevolking heeft in 2040 heeft naar verwachting een omvang die vergelijkbaar is met de potentiële beroepsbevolking in 2013 (Huisman et al., 2013). Ook na aanpassing met de stijging van de AOWleeftijd blijft de potentiële beroepsbevolking in Limburg, Zeeland en de krimpgebieden in Groningen dalen. Bij alle bevolkingsprognoses moet wel worden gewezen op de onzekerheidsmarges die vooral ontstaan doordat de toestroom van buitenlandse migranten erg kan fluctueren, en ook de binnenlandse migratiedynamiek tussen regio's plotseling kan omslaan. Vooral op de langere termijn kunnen de afwijkingen groot worden. 


\section{Figuur 8}

Daling van de potentiële beroepsbevolking in Nederland, Groningen, Zeeland en Limburg, 2014 (=100) tot 2025

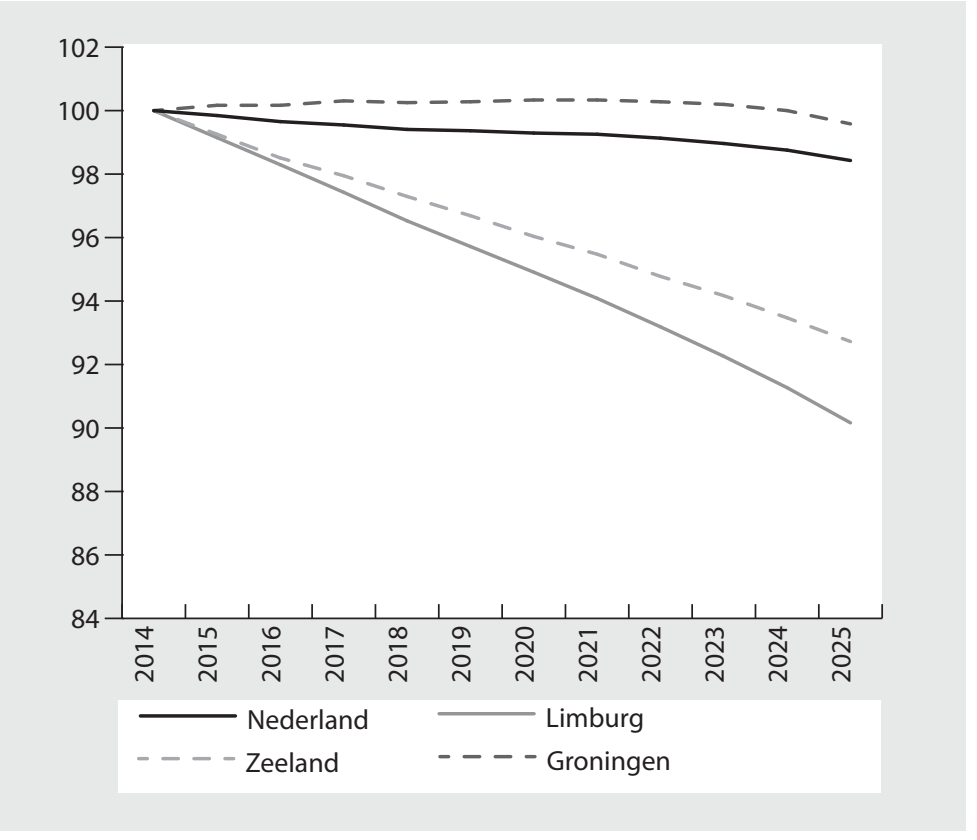

\section{Wat veroorzaakt kramp?}

De vraag is wat we moeten vrezen bij de demografische transitie in krimpgebieden. Waarom ontstaat kramp, en hoe kunnen we daaraan ontsnappen? Mijn invalshoek is dat de ernst van de kramp vooral wordt bepaald door de zogeheten aanpassingskosten. Deze zijn hoog als grote investeringen in economische activiteiten versneld moeten worden afgeschreven, inclusief de kennis en vaardigheden behorende tot het menselijk kapitaal van de beroepsbevolking. Versnelde afschrijvingen zijn het gevolg van onverwachte veranderingen in de omvang en samenstelling van de bevolking of de werkgelegenheid. Het gaat hierbij om woonwijken, schoolgebouwen, culturele en sportvoorzieningen met leegstand vanwege de krimp, maar ook om bedrijventerreinen die in onbruik zijn geraakt, infrastructuur die niet meer rendabel is (bijv. treinstations en lijnen), en de plotselinge afbouw van de werkgelegenheid door bedrijfssluiting of -verplaatsing. 
Het beste voorbeeld van grote aanpassingskosten in Limburg op de arbeidsmarkt is wat mij betreft de sluiting van de mijnen. Deze heeft nog decennialang een grote uitwerking gehad op de regionale economie en arbeidsmarkt (Langeweg, 2011). Maar op kleinere schaal kan men denken aan de afgewende sluiting van Nedcar, en de verplaatsing van kantoren van de Belastingdienst en Vodafone. In de Randstad kunnen de ontslagen werknemers bij een dergelijke afbouw van de werkgelegenheid waarschijnlijk gemakkelijker een nieuwe baan vinden dan in de dunnere regionale arbeidsmarkten van de perifere regio's.

Een belangrijke doelstelling van het krimpbeleid is te voorkomen dat er kramp ontstaat als gevolg van gemeentes die elkaar beconcurreren met woningbouw, de aanleg van bedrijventerreinen of het faciliteren van publieke voorzieningen. De bestuurders trachten met deze investeringen hun gemeente toch te laten groeien, maar creëren intussen overaanbod in de regio. Om een soepele demografische transitie mogelijk te maken en de kramp de verlichten richt het krimpbeleid zich in hoofdzaak op de volgende onderdelen (zie Deetman, 2011; Rijk/VNG/IPO, 2011; SER, 2011; Verwest en Van Dam, 2010):

- Bewustwording van krimp in de regio's die het betreft of gaat betreffen;

- Organiseren en stimuleren van bestuurskracht in de regio's, vooral wat betreft samenwerking tussen gemeentes en instellingen in het onderwijs en de zorg, met waar nodig ook financiële ondersteuning van de nationale overheid;

- Matigen en temporiseren van nieuwbouwprogramma's op de woningmarkt, en het stimuleren van sloop en herinrichting van de ruimte, bijvoorbeeld voor groenvoorziening en parken;

- Vitaliseren van de regionale economie door afbouw en aanpassing van winkelgebieden en bedrijventerreinprogramma's, het hergebruik van leegstaande gebouwen voor ondernemerschap en creatieve economische activiteiten, en het stimuleren van innovaties door de clustering van nieuwe veelbelovende economische activiteiten (campussen zoals Chemelot of Greenpark Venlo);

- Aanpassen van de zorgvoorzieningen aan de vergrijzende populatie, waarbij voorkeur gebruik wordt gemaakt van de nieuwste technologische mogelijkheden;

- Ruimtelijke concentratie van maatschappelijke, onderwijs-, cultuuren sportvoorzieningen zonder dat de breedte van het aanbod en de bereikbaarheid van de betreffende doelgroep te zeer in het geding komt.

- Leren van elkaar in de krimpproblematiek, in de vorm van bijvoorbeeld kennisuitwisseling in netwerken en experimentele projecten. 


\section{Figuur 9}

Krimpkreten in beleidsnota's, rapporten en artikelen

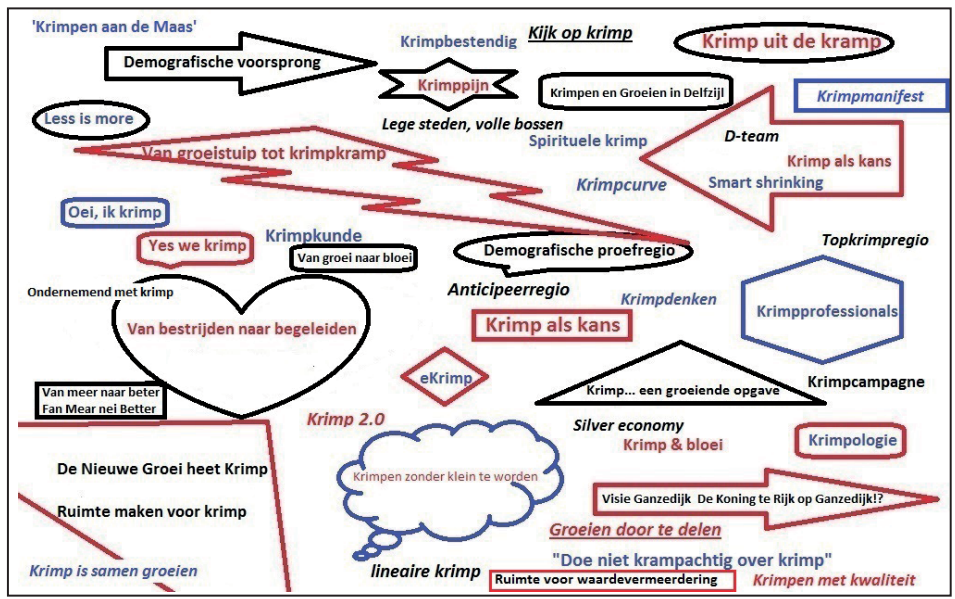

De psychologische aanpassingskosten van de krimp voor de bestuurders en de bevolking in de krimpregio's worden verlaagd door de bevolkingskrimp positiever te 'framen'. Bekend van de rouwverwerking is de acceptatiecyclus: eerst ontkennen, vervolgens verzet, dan apathie en tot slot accommodatie. Er wordt in het krimpdebat getracht een positieve draai te geven aan het onderwerp bevolkingskrimp. Krimp zit tussen je oren, het gaat om kwaliteit in plaats van kwantiteit, 'smart shrinking', krimp als kans, niet meer maar beter, etc. Krimpologen of krimpprofessionals zorgen voor een goede uitvoering van het beleid. In de bijgaande figuur heb ik de vele krimpkreten verzameld uit beleidsnota's, rapporten en artikelen. Daaruit blijkt tevens dat de titel van mijn oratie, 'Krimpen zonder kramp', niet bijster origineel is voor degenen die de grijze literatuur en artikelen over demografisch krimp gevolgd hebben. "Doe niet zo krampachtig over krimp" was zelfs de kop van een artikel in de Volkskrant in 2010. En eerder verscheen er een artikel met de titel "Krimp uit de Kramp" (Haartsen, 2008). In elk geval blijkt een krimpende bevolking tot de verbeelding te spreken, getuige de vele woordspelingen, uitdrukkingen en metaforen die de laatste jaren voorbij zijn gekomen om een positieve boodschap over te brengen over het verschijnsel bevolkingskrimp. 


\section{Regionaal arbeidsmarktbeleid en krimp}

Regionaal arbeidsmarktbeleid is in de grote hoeveelheid nota's en rapporten over krimp meestal geen apart hoofdstuk, en wordt het vaak opgenomen onder een hoofdstuk over het vitaliseren van de regionale economie. De verantwoordelijkheid voor een goed functionerende regionale arbeidsmarkt ligt voor een belangrijk deel bij gemeentes en provincies. Bovendien zijn er 35 arbeidsmarktregio's waarin het regionale arbeidsmarktbeleid vorm gegeven kan worden. Het te voeren arbeidsmarktbeleid gaat meestal uit van de veronderstelling dat de toekomstige schaarste op de arbeidsmarkt groter wordt doordat de grote cohorten aan oudere ervaren arbeidskrachten (de 'babyboomgeneratie') slechts deels worden vervangen door de kleinere cohorten aan jongeren die instromen op de arbeidsmarkt.

Uit de arbeidsmarktprognoses van het ROA (2013) voor periode 20132018 blijkt inderdaad dat de instroom van jongeren op de arbeidsmarkt in veel beroepen onvoldoende groot is om de vervangingsvraag aan ouderen die uittreden op te vangen. In de economische literatuur is dit echter niet evident. De alternatieve hypothese is dat werkgevers de bedrijvigheid afbouwen in regio's waar minder jongeren op de arbeidsmarkt komen, waardoor de werkloosheid juist toeneemt. Denk hierbij ook aan wat ik eerder heb opgemerkt over het werk dat in de Randstad het wonen volgt. Om de relatie te bepalen zijn er verschillende empirische studies verricht. De studie van Garloff et al. (2013) lijkt de meest overtuigende. Zij vinden dat de arbeidsmarktintrede van kleinere cohorten van jongeren een lagere werkloosheid tot gevolg heeft. ${ }^{4}$ Vooral voor krimpregio's waar de vergrijzing en ontgroening toeslaat, kan de schaarste aan arbeidskrachten dus toenemen door een kleiner wordend arbeidsaanbod. Hoewel de effecten klein zijn, onder andere omdat geografische mobiliteit zorgt voor een zekere convergentie in de werkloosheidspercentages tussen krimp- en groeiregio's, bevelen Garloff et al. (2013) aan om beleid te voeren gericht op het verhogen van de arbeidsparticipatie.

Om de aanpassingskosten van een krimpende bevolking in de hand te houden, en kramp op de arbeidsmarkt zoveel mogelijk te voorkomen, zou derhalve het arbeidspotentieel zo goed mogelijk gebruikt moeten worden. Dat betekent zuinig omgaan met je toekomstige arbeidspotentieel, vooral in de krimpregio's. In het rapport van de OECD (2013) over Nederland worden specifiek genoemd:

4 Ze gebruiken een dataset van regionale arbeidsmarkten in West-Duitsland in de periode van 1978 tot 2009 . 
- Stimuleren van de arbeidsparticipatie onder vrouwen en ouderen van voor en na 65 jaar oud;

- Ontwikkelen van bedrijvigheid die aansluit bij de kwaliteiten van de beroepsbevolking;

- Aanpassen van het onderwijsaanbod aan de vraag van werkgevers op de arbeidsmarkt en aan het clusterbeleid van sectoren en bedrijven;

- Stimuleren van allianties tussen onderwijsinstellingen en werkgevers, vooral wat betreft het praktijkgericht onderwijs.

\section{Regionaal arbeidsmarktbeleid op drie opleidingsniveaus}

Daarnaast vind ik het zinvol om bij het te voeren regionale arbeidsmarktbeleid onderscheid te maken naar drie opleidingsniveaus.

\section{Lager opgeleiden}

De activering aan de onderkant van de arbeidsmarkt is van groot belang omdat de (netto) arbeidsparticipatie onder de lager opgeleiden lager ligt dan 50\% in vrijwel alle regio's van het land. In Zuid-Limburg is de arbeidsparticipatie onder lager opgeleiden het laagst van alle regio's (CBS, Statline). Bovendien zijn in grens- en krimpregio's de lager opgeleiden oververtegenwoordigd (Marlet et al., 2014). ${ }^{5}$ De grote vraag is hoe lager opgeleiden duurzaam aan het werk kunnen blijven als ze vooral op flexibele banen worden ingezet, zonder dat er geïnvesteerd wordt in hun menselijk kapitaal door opleiding en training (Cörvers et al., 2011). Lager opgeleiden die werk hebben, kunnen bovendien door informeel leren de noodzakelijke competenties voor een verdere loopbaan opdoen mits er voldoende aandacht is voor het creëren van 'leerrijke werkplekken'. Werkgevers zouden in samenspraak met onderwijsinstellingen, UWV en lokale overheden kunnen zorgen voor een betere invulling van flexibele contracten zodat er meer ruimte ontstaat voor formeel en informeel leren van laagopgeleiden.

\section{Middelbaar opgeleiden}

Door de behoefte aan niet-routinematige persoonlijke dienstverlening, kan de arbeidsvraag naar lager opgeleid personeel nog redelijk in stand blijven, terwijl de drang naar kennis en innovatie in bijvoorbeeld de top-

5 Parkstad Limburg heeft het hoogste percentage lager opgeleiden van alle stadsgewesten in Nederland (meer dan $40 \%$ is lager opgeleid). Daarnaast heeft Parkstad Limburg van alle regio's het grootste aandeel 55- tot 64-jarigen in de potentiële beroepsbevolking, en een hoog aandeel arbeidsongeschikten (CBS Statline). Daardoor is de gemiddelde arbeidsparticipatie in Parkstad Limburg erg laag. 
sectoren juist de vraag naar hooggekwalificeerd personeel stimuleert. Per saldo neemt vooral de werkgelegenheid voor middelbaar opgeleiden flink af (Goos et al., 2014), omdat hun werkzaamheden relatief vaak routines bevatten die als gevolg van ontwikkelingen in de ICT geautomatiseerd kunnen worden. ${ }^{6}$ Middelbaar opgeleiden zijn vergeleken met de hoger opgeleiden sterk op de eigen regio gericht (Hensen et al., 2009), waardoor vooral krimpregio's vaak met dalende werkgelegenheid op middelbaar beroepsniveau worden geconfronteerd.

$\mathrm{Er}$ is een voortdurende discussie over de arbeidsmarktrelevantie van middelbare beroepsopleidingen die door ROC's worden aangeboden. Omdat de arbeidsmarktperspectieven van de verschillende opleidingsrichtingen op mbo-niveau van jongeren lopen zo sterk uiteen lopen is het evident dat dit potentieel aan jongeren veel beter benut kan worden. Er zijn immers te veel opleidingen waarvan minder dan de helft van de jongeren een baan vindt, ook op mbo-niveau 4, terwijl bij andere opleidingen alle jongeren aan het werk komen. ${ }^{7}$ Maatregelen als het verplicht stellen van de studiebijsluiter en het aanscherpen van de zorgplicht arbeidsmarktperspectief voor ROC's moeten de transparantie over de arbeidsmarktrelevantie van middelbare beroepsopleidingen vergroten. Dalende leerlingenaantallen in krimpgebieden kunnen leiden tot een concentratie van (de relatieve dure technische) opleidingen op één locatie in de regio, wat een verschuiving in de studiekeuze in andere richtingen dan de techniek kan bewerkstelligen. Krimp kan dan indirect bijdragen aan een verschuiving van de studiekeuze in de richting van minder arbeidsmarktrelevante studierichtingen. ${ }^{8}$

\section{Hoger opgeleiden}

Hoger opgeleiden zijn van groot belang voor de regionale economische ontwikkeling. Ten eerste zijn er positieve multipliereffecten op de economische groei en de werkgelegenheid. Meer hoger opgeleiden in een regio leidt tot een hogere lokale consumptie, betere lokale voorzieningen en meer regionale werkgelegenheid, ook voor de lageren middelbaaropgeleiden. Ten tweede leidt de R\&D-functie van hoger opgeleiden aan kennisinstellingen tot innovatie, waarvan regio's door de daarbij horende lokale externaliteiten in de vorm van kennis-spillovers

6 In dit verband wordt de automatisering in de bankensector vaak als voorbeeld genoemd (bijv. Jonker en De Groot, 2013).

7 Zie hoofdstuk 5 in ROA (2013), Bertrand-Cloodt et al. (2013) en (Cörvers et al., 2014).

$8 \quad$ Zie Bertrand-Cloodt et al. (2011) voor een onderzoek aan de hand van gegevens in Noord-Limburg en Oost-Brabant. 
kunnen profiteren. Uit eerder onderzoek blijkt dat een hogere regionale innovatiegraad hoger opgeleide afgestudeerden aantrekt, maar ook dat de netto instroom van afgestudeerden uit andere regio's de regionale kennisaccumulatie bevordert (Faggian en McCann, 2009).

Beleidsmakers in de grensregio's van Nederland uiten vaak hun zorgen over de zogenaamde 'brain drain' vanuit de krimpgebieden naar het Westen van het land. Hoger opgeleiden vertrekken naar regio's met de beste carrièremogelijkheden en arbeidsvoorwaarden, maar er is ook zogenaamde 'forced migration' omdat er te weinig werkgelegenheid is in de krimpregio waar men woont of afstudeert (Cörvers en Ramaekers, 2010; Venhorst en Cörvers, 2010; Venhorst, 2012). Voor de hoger opgeleiden is geografische mobiliteit een instrument om een betere aansluiting te bewerkstelligen tussen de afgeronde opleiding en de baan. Voor beleidsmakers in krimpregio's zijn er kansen om 'forced migration' te voorkomen door het initiëren van economische activiteiten die zoveel mogelijk aansluiten bij de opleidingsachtergrond van de hoger opgeleiden in hun regio.

Daardoor is het voor regionale beleidsmakers in krimpregio's van groot belang om de geografische mobiliteit van hoger opgeleiden te monitoren. Door de aantrekkelijkheid en het groeipotentieel van hun regio te beoordelen, kunnen er maatregelen worden genomen om de regio aantrekkelijk te maken of houden. Dit geldt in het bijzonder als er door de aanwezigheid van een hogeschool of universiteit in een krimpregio (zoals Zuid-Limburg) voldoende potentieel aanbod is van hoger opgeleiden. De zogeheten KennisAs-projecten die door een aantal samenwerkingspartners in Limburg worden opgestart, waaronder de Provincie Limburg, Maastricht University en Zuyd hogeschool, dragen zeker bij aan een aantrekkelijker werkklimaat voor hoger opgeleiden. Dat er desondanks nog veel werk aan de winkel is voor Limburg toont figuur 10. De figuur is gebaseerd op prognoses van de werkgelegenheidsontwikkeling in de diverse regio's, welke door het ROA zijn opgesteld (Clerx et al., 2014). Hieruit blijkt dat de (uitbreidings)vraag naar hoger opgeleiden in de Limburgse regio's na de Achterhoek en de Gooi- en Vechtstreek het laagst is van alle 35 regio's. 


\section{Figuur 10}

Verwachte uitbreidingsvraag in 35 arbeidsmarktregio's, als jaarlijks percentage van de werkgelegenheid in 2012, periode 2013-2018

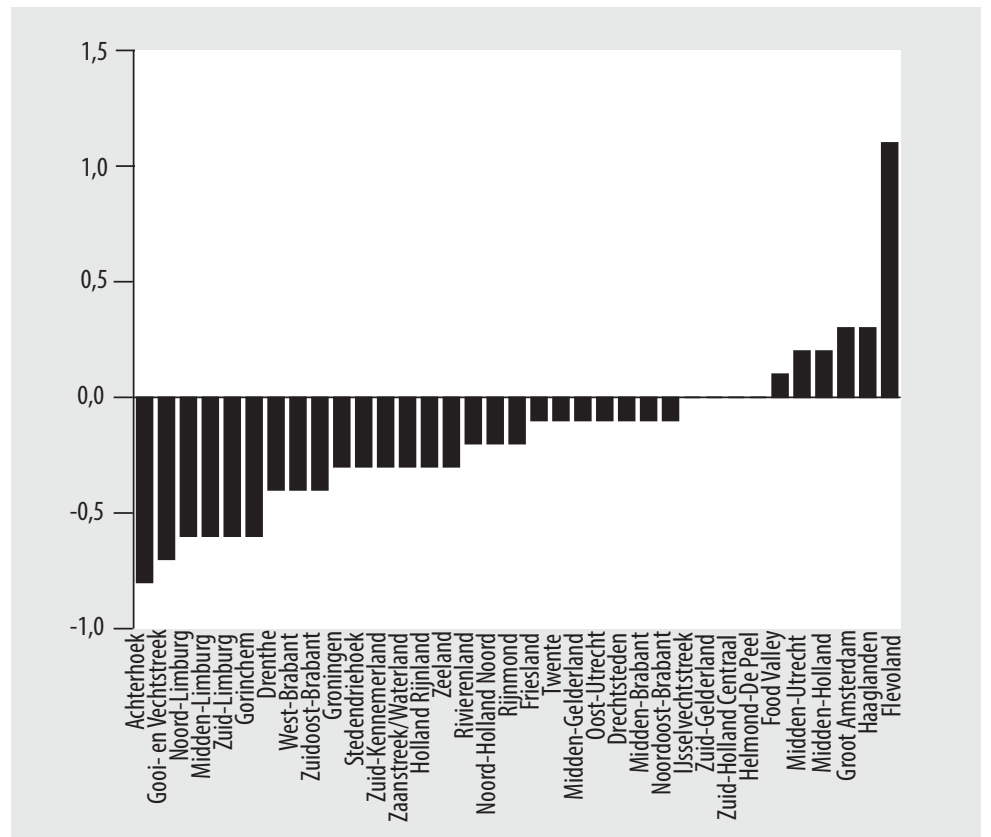

Bron: ROA

\section{Slot}

Het begin van mijn betoog was vooral gericht op de bevolkingsgroei in Limburg. Ik heb laten zien dat het erg moeilijk is om actief te bewerkstelligen dat de bevolking in Limburg groeit in plaats van krimpt. Dit komt omdat de vruchtbaarheid laag is, omdat de buitenlandse immigratie sterk afhankelijk is van de economische groei, en omdat er meer mensen uit Limburg vertrekken naar andere delen van het land dan vice versa. Binnen Nederland oefenen met name de Randstad en de vier grote steden een grote aantrekkingskracht uit op de binnenlandse migranten. Ik heb betoogd dat dat vooral te maken heeft met agglomeratievoordelen, die als een magneet bedrijvigheid en mensen aantrekken. Naar verwachting blijft dit ook zo door de voortgaande nieuwbouw in de grote steden, waardoor vooral Noord- en Zuid-Holland en Utrecht mensen uit andere provincies zullen aantrekken. 
Hoewel De Groot et al. (2010) laten zien dat de groei van steden op de langere termijn voor een belangrijk deel onvoorspelbaar is en door toevallige gebeurtenissen wordt beïnvloed, hetgeen de maakbaarheid van verstedelijking beperkt, is het erg moeilijk om tegen de stroom in te roeien. De kramp in krimpgebieden ontstaat als er hoge aanpassingskosten zijn. Als je niet anticipeert zijn die kosten groter dan als je wel anticipeert. Dan gaat het vooral om het aanpassen van publieke voorzieningen door concentratie en afbouw. De vele rapporten en beleidsnota's over krimp zijn er op gericht de bewustwording over bevolkingskrimp te stimuleren, de problemen aan te kaarten, oplossingen te bieden, en de nieuwe mogelijkheden te inventariseren die door bevolkingskrimp ontstaan.

Het regionale arbeidsmarktbeleid wijkt qua thema's niet af van de nationale agenda. Het gaat vooral om het verhogen van de arbeidsparticipatie en het verbeteren van de aansluiting tussen het onderwijs en de arbeidsmarkt in de regio. Ik heb betoogd dat het zinvol is om in het krimpbeleid te differentiëren naar lager, middelbaar en hoger opgeleiden. De hoger opgeleiden zijn voor een regionale arbeidsmarkt van belang als aanjager voor economische en werkgelegenheidsgroei. Hun grote geografische mobiliteit biedt zowel kansen als bedreigingen voor krimpregio's. De geringe geografische mobiliteit van lager opgeleiden betekent juist dat zij vrijwel geheel op de eigen regio zijn aangewezen, en dat er vooral op lokaal niveau inspanningen moeten worden verricht om de lage arbeidsparticipatie van vooral ouderen en vrouwen te stimuleren, hetgeen van groot belang is bij een krimpend arbeidsaanbod. Ook de middelbaar opgeleiden zijn in sterke mate regionaal gebonden. Vooral op krimpende arbeidsmarkten is het van groot belang dat jongeren een middelbare beroepsopleiding kiezen die aansluit bij de regionale arbeidsvraag, zodat zo weinig mogelijk menselijk kapitaal verspild wordt.

Er zijn specifieke problemen rondom krimp die een grensprovincie als Limburg raken. Netto verliest de regio jonge academici aan de rest van het land, vooral aan de Randstad. Hoe kan de regio dan toch leegloop voorkomen? Ten eerste door meer immigranten van vlak over de grens, maar ook uit andere gebieden uit Europa aan te trekken. Voor zover het hier gaat om hoger opgeleiden, is het nodig dat de regio zich internationaal goed profileert, en ervoor zorgt dat deze groep gemakkelijk aan het werk kan, een aantrekkelijke woning kan vinden en dat er voldoende onderwijsen culturele voorzieningen voor hen en hun familie zijn. Voor zover het lager opgeleide migranten betreft moet er extra aandacht worden besteed aan integratie en scholing (Muysken et al., 2007). De onderzoeksvraag is hoe de samenstelling van de groep immigranten is c.q. zal veranderen door de bevolkingsdaling (bijv. meer ruimte, lagere woningprijzen, 
kettingmigratie, etc.), en wat zij het meeste nodig hebben om een succesvolle integratie en vestiging in Limburg mogelijk te maken. Ten tweede door te proberen dat de buitenlandse studenten die hier studeren na hun studie op zijn minst enige tijd in Limburg blijven werken of een eigen bedrijf starten (SER, 2013). De belangrijkste onderzoeksvraag daarbij is het in kaart brengen van de factoren die hierop in positieve of negatieve zin van invloed zijn. Ten derde door de retourmigratie naar Limburg te bevorderen. De vraag is dan hoe oud-provinciegenoten het beste kunnen worden verleid om terug te keren.

\section{Dankwoord}

Als alumnus van de Universiteit Maastricht kreeg ik in 1992 de mogelijkheid om een proefschrift te schrijven onder begeleiding van prof. Hans Heijke en toen nog doctor Andries de Grip, beiden verbonden aan het Researchcentrum voor Onderwijs en Arbeidsmarkt (ROA). Sindsdien weet ik niet beter dan dat ik met hen heb samengewerkt. Aanvankelijk onder hun hoede, later als zelfstandig onderzoeker en tegenwoordig als professor. Hans is de 'founding father' van het ROA, en heeft het ROA meer dan 20 jaar als directeur geleid. Hij is dan wel met emeritaat, maar ik werk nog steeds met veel genoegen met hem samen op diverse onderzoeksprojecten. Andries leidt tegenwoordig als één van de twee hoogleraar-directeuren het ROA. Zonder Hans en Andries had ik hier waarschijnlijk niet gestaan, en ik ben hen dan ook veel dank verschuldigd.

Ook wil ik mijn collega's bij het ROA bedanken met wie ik al die jaren op een fijne manier heb kunnen samenwerken. Dat is niet vanzelfsprekend, want de samenwerking wordt nogal eens op de proef gesteld met alle deadlines voor offertes, rapporten en papers. En de meesten weten wat een deadline bij mij betekent: dat die gehaald wordt, al is het dan vaak wat aan de late kant. Dus bedankt collega's en dames van het secretariaat voor jullie geduld en toewijding. Ook veel dank aan Joyce en Melissa, en natuurlijk mijn naaste collega's in het managementteam Rolf van der Velden en Didier Fouarge. Onderzoekers van wie ik al die jaren aan de economische faculteit op een fijne manier veel van onderzoek heb geleerd zijn niet alleen Hans en Andries, maar ook Lex Borghans en Maarten Vendrik. Leuk onderzoek doen is wat mij betreft niet alleen een kwestie van het opleveren van een hoogwaardige publicatie, maar ook van een fijn persoonlijk contact bij de uitvoering van het onderzoek en buiten werktijd. Daarom zijn een wandeling tijdens de lunch, een visite zomaar tussendoor of voor een verjaardag, of samen een biertje drinken in de kroeg wat mij betreft een hele welkome aanvulling op al het onderzoekswerk. 
Daarnaast wil het College van Bestuur bedanken voor het in mij gestelde vertrouwen, evenals de Provincie Limburg en Neimed voor het mogelijk maken van de leerstoel. Neimed is het Nederlands Expertise en Innovatiecentrum Maatschappelijke Effecten Demografie, dat met steun van Parkstad Limburg en de Provincie Limburg is opgericht als één van de pijlers voor de kennis over bevolkingsdaling. Ik heb al een aantal bijzondere activiteiten van Neimed mogen bijwonen, waaronder de jaarlijkse krimplezing. Als nieuwe kracht bij Neimed zie ik uit naar verdere samenwerking met Wim Didderen en Nol Reverda en de andere collega's bij Neimed.

Dan wil ik nog graag al mijn vrienden uit mijn studententijd bedanken, van wie een groot deel vandaag aanwezig is, uit interesse voor mijn persoon en niet per se voor mijn onderzoekswerk. Door met hen te zijn kom ik gelukkig ook aan iets anders toe dan mijn onderzoek. Velen van hen zie ik slechts enkele keren per jaar, sommige jaren niet. Maar als we elkaar zien, is het altijd vertrouwd, en voel ik me weer een beetje de student van toen. Vanwege de deadline voor het drukken van mijn oratieboekje kon ik een paar weken geleden met een aantal vrienden helaas toch niet mee naar Dresden, maar dat halen we nog wel in. Bijzonder blij ben ik met de aanwezigheid van Guus van Sonsbeek en Rob Maessen, die sinds een jaar weer collega van mij is aan de universiteit. Ik heb met hen gestudeerd en zij waren mijn paranimfen in 1999, toen ik mijn doctorstitel behaalde, en bijna exact 15 jaar later zijn ze er tot mijn grote genoegen weer bij.

Mijn ouders, mijn kinderen en hun moeder heb ik al bedankt bij mijn oratie aan de Universiteit van Tilburg op 6 juni jongstleden. Ik heb die rede zelfs aan mijn ouders opgedragen. Mijn dank is er nu niet minder om, maar ik wil afsluiten met de buurt waar ik als volwassene de meeste jaren heb gewoond. Ook al ben ik niet minder blij met Wolder waar ik nu woon, ik wil even stilstaan bij de bijzondere tijd dat ik in de Ravelijn woonde. De Ravelijnbuurt werd decennialang met sloop bedreigd. Het is de oudste woonschool van Nederland die nog in zijn geheel behouden is gebleven. Mijn tijd daar was de mooiste, niet alleen omdat mijn kinderen Lena, Bettie en Silke opgroeiden op het plein van de Ravelijn, maar ook door de gezamenlijke strijd tegen de sloop met Jacqueline, Geert-Jan, Christa, Pim, Thijs en vele anderen. Ik kom nog steeds heel graag terug in de Ravelijn, voor een bezoekje of een feest, en dat geldt ook voor mijn kinderen. Die strijd met de woningcorporatie duurde wel 15 jaar en eiste veel tijd en energie. In de krant werden de woningen door de toenmalige directeur van de woningcorporatie betiteld als 'plaggenhutten'. Tegenwoordig vindt bijna iedereen de monumentenstatus van de Ravelijn vanzelfsprekend. Dit laat wat mij betreft zien dat 
roeien tegen de stroom in soms wel zin heeft, en dat het zelfs mogelijk is de stroom te verleggen.

Ik heb gezegd. 


\section{Literatuur}

Bertrand-Cloodt, F. Cörvers, H. Heijke en J. van Thor (2011), Verkenning van de invloed van reisafstand op de keuze voor een middelbare beroepsopleiding, ROA-TR-2011/1, Maastricht University

Bertrand-Cloodt, D., F. Cörvers, S. Dijksman en J. van Thor (2013), Doelmatigheid mbo in de regio, ROA-TR-2013/1, Maastricht University.

Brakman, S., H. Garretsen and Ch. van Marrewijk (2003), An introduction to geographical economics, Cambridge University Press, Cambridge.

Clerx, R., F. Cörvers, en D. Fouarge (2014), Regionale arbeidsmarktprognoses 2013-2018, methodiek en resultaten, ROA-TR-2014/4, Universiteit Maastricht.

Ciccone, A. (2002), Agglomeration effects in Europe, European Economic Review, Vol. 46, pp. 213-227.

Ciccone, A. and R.E. Hall (1996), Productivity and the Density of Economic activity, American Economic Review, Vol. 86, pp. 54-70.

Cörvers, F. (2013), Managing territorial demographic transitions and declining labour supply, challenges for Zeeland. In: C. Martinez, S. Giguère and S. Arzeni (eds.), Demographic Change in the Netherlands: Strategies for resilient labour markets, OECD, Paris, pp. 136-164.

Cörvers, F., R. Euwals en A. de Grip (2011), Labour Market Flexibility in the Netherlands, CPB/ROA-report, Den Haag.

Cörvers, F., M. de Hoon en C. Meng (2014), Macrodoelmatigheid mbo: Inkadering arbeidsmarktperspectief, ROA-R-2014/1, Universiteit Maastricht.

Cörvers, F., J. Muysken, C. de Neubourg en A. Schliwen (2009), Arbeidsmigratie. In: WODC, Migratie naar en vanuit Nederland - een eerste proeve van de Migratiekaart, Cahiers 2009-03, WODC/Maastricht University, Den Haag, pp. 43-92.

Cörvers, F. en G. Ramaekers (2010), De strijd om kenniswerkers tussen provincies, Economisch Statistische Berichten, Vol. 95, pp. 438-441.

Dam, F. van, C. de Groot en F. Verwest (2010), Zeven misverstanden over de ruimtelijke gevolgen van demografische krimp. In: F. Verwest en F. van Dam (red.), Van bestrijden naar begeleiden: demografische krimp in 
Nederland Beleidsstrategieën voor huidige en toekomstige krimpregio's, Planbureau voor de Leefomgeving, Den Haag/Bilthoven, pp. 63-66.

Decisio (2014), Economische analyse van het aantal internationals in Zuid-Nederland, Eindrapport, Opgesteld in opdracht van Holland Expat Center*South, 15 februari, Amsterdam.

Deetman, W.J., J.H.H. Mans en P. Zevenbergen (2011), Ruimte voor waardevermeerdering, Eindrapportage Adviescommissie Deetman, Bevolkingskrimp Limburg, Provincie Limburg, 18 februari.

Faggian, A. and P. McCann (2009), Human capital, graduate migration and innovation in British regions, Cambridge Journal of Economics, Vol. 33, pp. 317-333.

Glaeser, G.L., J. Kolko and A. Saiz (2001), Consumer city, Journal of Economic Geography, Vol. 1, pp. 27-50.

Glaeser, G.L. and D.C. Mare (2001), Cities and Skills, Journal of Labor Economics, Vol. 19, pp. 316-334.

Goos, M., A. Manning and A. Salomons (2014), Explaining Job Polarization: Routine-Biased Technological Change and Offshoring, American Economic Review, Vol. 104, pp. 2509-2526.

Graaff, T. de, F. van Oort en S. Boschman (2008), Woon-werk dynamiek in Nederlandse gemeenten, Ruimtelijk Planbureau en NAI Uitgevers, Den Haag/Rotterdam.

Grip A. de, en J. van Thor (2013), Limburg province: Population stagnation and ageing - The challenges of revitalising the regional economy, In: C. Martinez, S. Giguère, and S. Arzeni (eds), Demographic Change in the Netherlands: Strategies for resilient labour markets, OECD, Paris pp. 105-141.

Groot, S.P.T., H.L.F. de Groot and M.J. Smit (2014), Regional wage differences in the Netherlands: Microevidence on agglomeration externalities, Journal of Regional Science, Vol. 54, pp. 503-523.

Groot, H. de, G. Marlet, C. Teulings en W. Vermeulen (2010), Stad en land, $\mathrm{CPB}$, Den Haag.

Haartsen, T. (2008), Krimp uit de Kramp, Noorderbreedte, Vol. 32, pp. 6-11. 
Hensen, M., R. de Vries and F. Cörvers (2009), The role of geographic mobility in reducing education-job mismatches in the Netherlands, $\mathrm{Pa}$ pers in Regional Science, Vol. 88, pp. 667-682.

Hospers, G.J. (2010), Krimp!, Uitgeverij SUN, Amsterdam.

Huisman, C., A. de Jong, C. van Duin en L. Stoeldraijer (2013), Regionale prognose 2013-2040, Vier grote gemeenten blijven sterke bevolkingstrekkers, 1 oktober, CBS/PBL.

Jonker, S. en G. de Groot, Mbo-functies en zakenbankiers verdwijnen van Zuidas, Financieele Dagblad, 27 mei.

Kooiman, N., J. Latten en H. Nicolaas (2013), Bevolkingskrimp Limburg geremd door toegenomen immigratie, Webartikel CBS, 28 augustus.

Langeweg, S. (2011), Mijnbouw en arbeidsmarkt in Nederlands-Limburg, Herkomst, werving, mobiliteit en binding van mijnwerkers tussen 1900 en 1965, Maaslandse Monografieën, Vol. 75, Uitgeverij Verloren, Hilversum.

Marlet, G., A. Oumer, R. Ponds en C. van Woerkens (2014), Groeien aan de grens, Kansen voor grensregio's, VOC Uitgevers, Nijmegen.

Muysken, J., F. Cörvers en T. Ziesemer (2007), Immigratie als wapen in de strijd tegen de vergrijzing, Kwartaalschrift Economie, Vol. 4, Themanummer Vergrijzing, pp. 475-496.

Myrdal, G. (1957), Economic Theory and Underdeveloped Regions, Duckworth, London.

OECD (2012), Demographic Change and Local Development: Shrinkage, Regeneration and Social Dynamics, Paris.

OECD (2013), Demographic Change in The Netherlands: Strategics for Resilient Labour Markets, Paris.

Rauch, J.E. (1993), Productivity Gains from Geographic Concentration of Human Capital: Evidence from the Cities, Journal of Urban Economics, Vol. 34, pp. 3-33.

Reverda, N. (2011), Over Krimp, Een sociologisch perspectief op bevolkingsdaling, CESRT/NEIMED, Zuyd Hogeschool, Maastricht. 
Reverda, N., M. Hermans en M. Rocak (2012), People's climate in shrinking areas: the case of Heerlen, the Netherlands, In: OECD (2012), Demographic Change and Local Development: Shrinkage, Renegeneration and Social Dynamics, Paris, pp. 249-256.

Rijk/VNG/IPO (2011), Interbestuurlijke Voortgangsrapportage Bevolkingsdaling, bijlage bij Kamerbrief 2011048273, 30 juni.

ROA (2013), De arbeidsmarkt naar opleiding en beroep tot 2018, ROAR-2013/11, Universiteit Maastricht.

SER (2011), Bevolkingskrimp benoemen en benutten, Advies uitgebracht aan de ministers van BZK, EZ en LNV, Nr. 3 - maart, Den Haag.

SER (2013), Make it in the Netherlands!, Advies over binding van buitenlandse studenten aan Nederland, Advies 13/01, april, Den Haag.

Venhorst, V.A. (2012), Smart move? The spatial mobility of higher education graduates, Proefschrift RUG, Groningen.

Venhorst, V. en F. Cörvers (2010), Entry into the working life: spatial mobility and job-match quality of higher educated graduates, paper presented at the NARSC Conference, Nov. 11th-13th, Denver, Colorado, U.S.A.

Verwest, F. en F. van Dam (2010, red.), Van bestrijden naar begeleiden: demografische krimp in Nederland Beleidsstrategieën voor huidige en toekomstige krimpregio's, Planbureau voor de Leefomgeving, Den Haag/Bilthoven.

WODC (2009), Migratie naar en vanuit Nederland - een eerste proeve van de Migratiekaart, Cahiers 2009-03, WODC/Maastricht University, Den Haag. 
NEDERLANDS EXPERTISE EN INNOVATIECENTRUM MAATSCHAPPELIJKE EFFECTEN DEMOGRAFISCHE KRIM

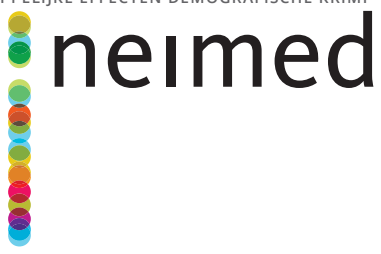

provincie limburg

gesubsidieerd door de Provincie Limburg 
